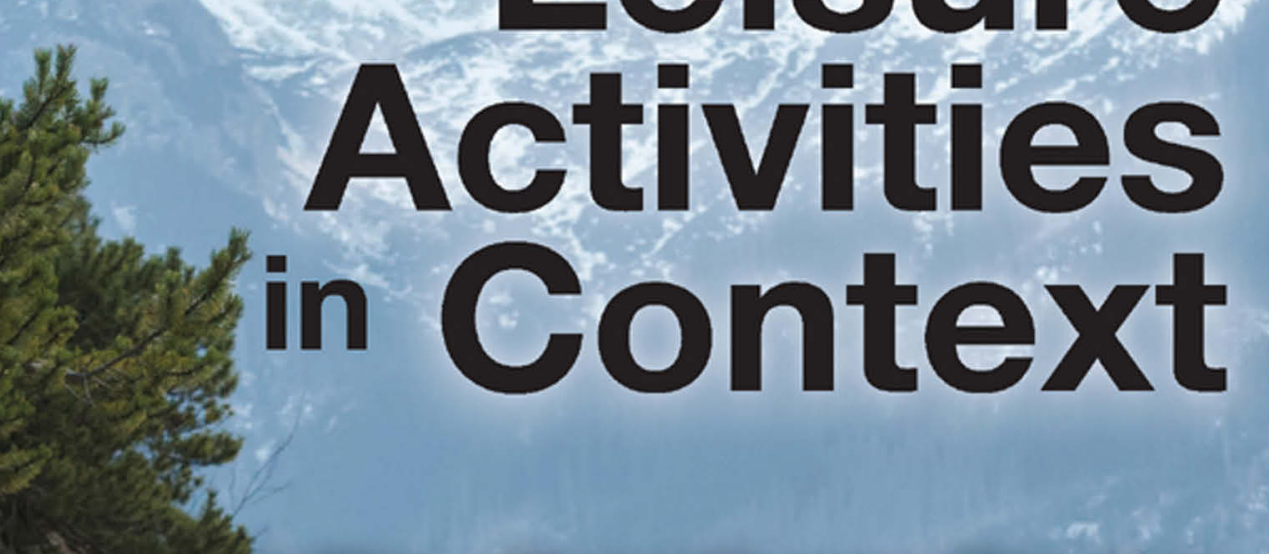

A. A Micro-Macro/Agency-Structure

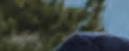

\title{
Interpretation of Leisure
}

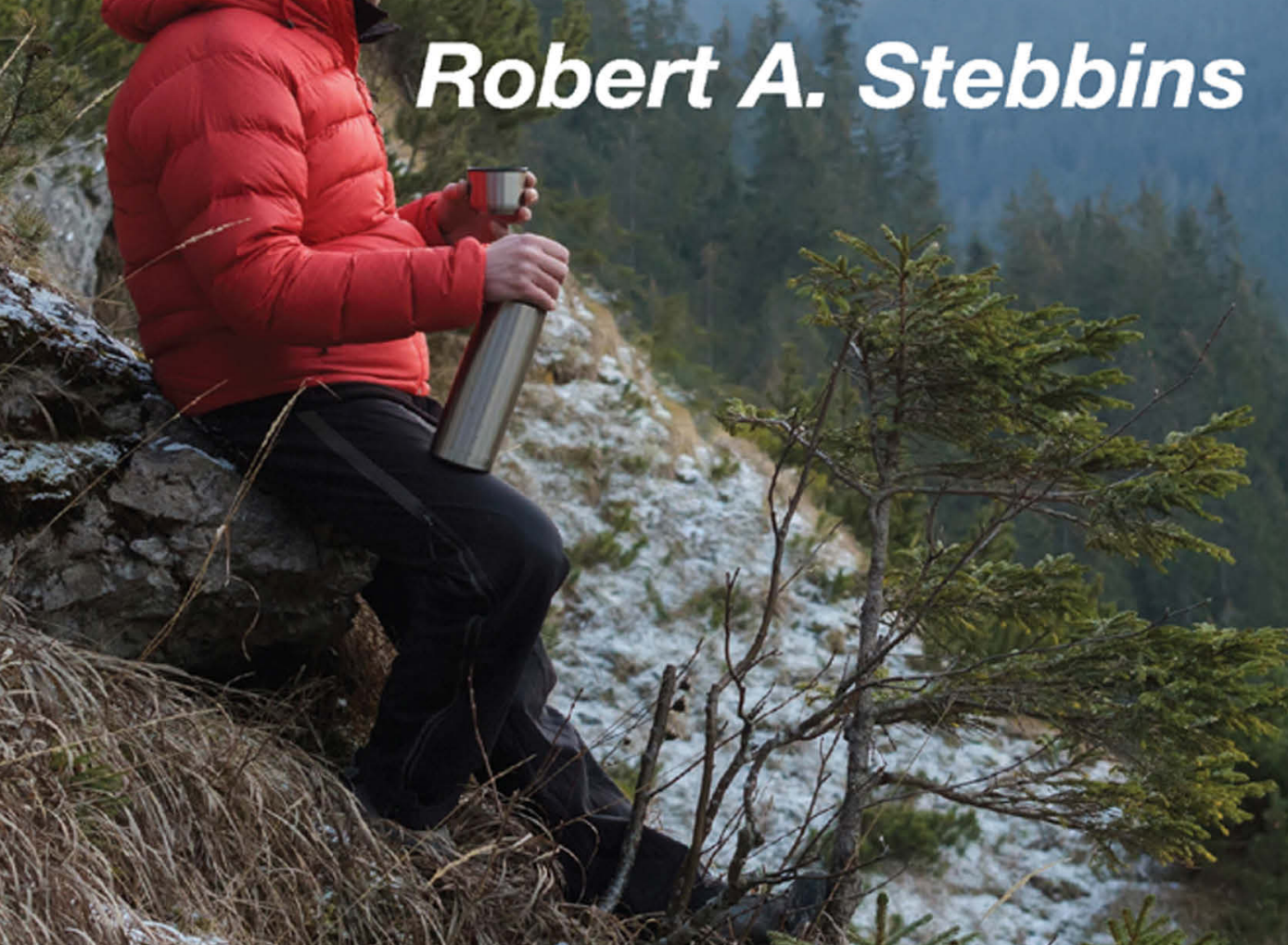




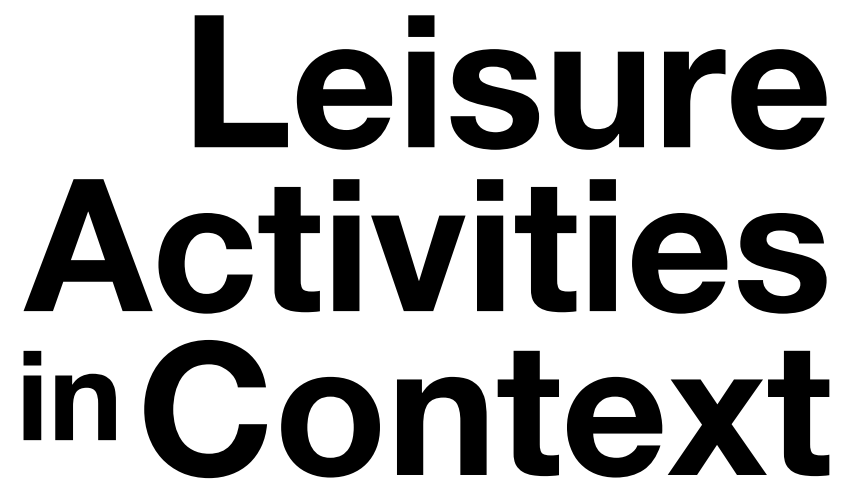



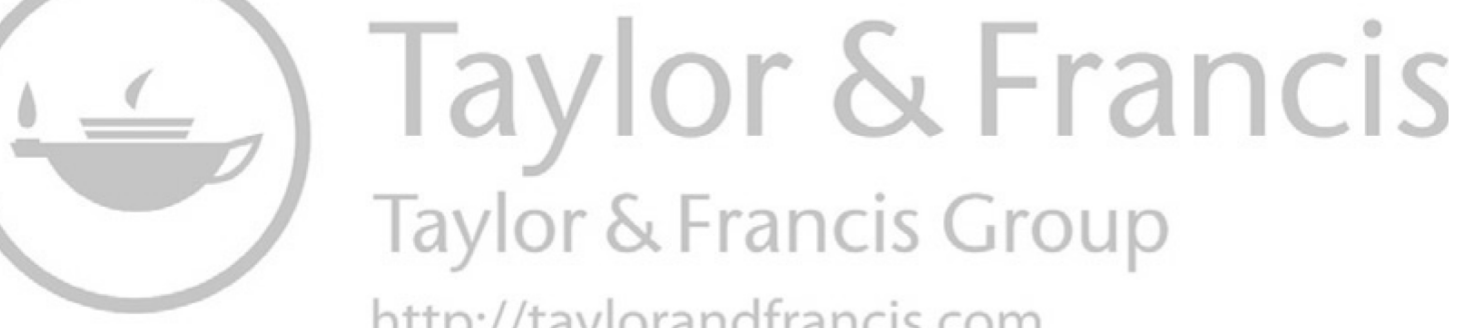
http://taylorandfrancis.com 


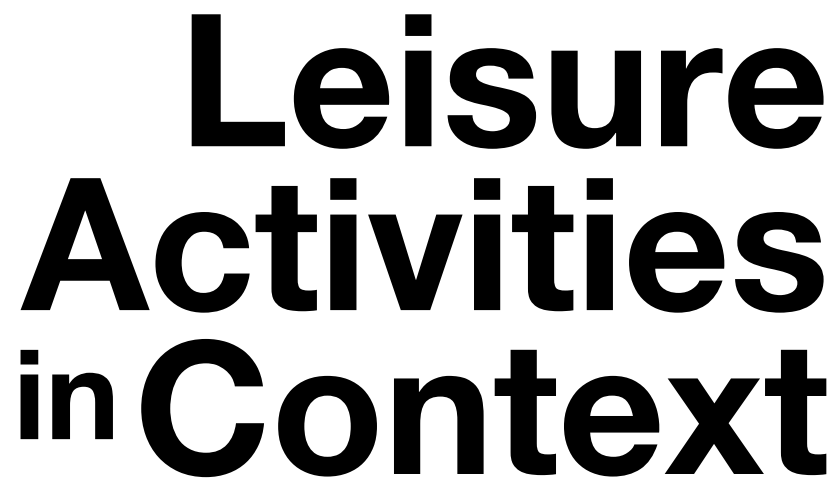

A Micro-Macro/Agency-Structure Interpretation of Leisure

\section{Robert A. Stebbins}

Routledge

LONDON AND NEW YORK 
First published 2017 by Transaction Publishers

Published 2017 by Routledge

2 Park Square, Milton Park, Abingdon, Oxon OX14 4RN

711 Third Avenue, New York, NY 10017, USA

Routledge is an imprint of the Taylor \& Francis Group, an informa business

Copyright $\odot 2017$ by Taylor \& Francis.

All rights reserved. No part of this book may be reprinted or reproduced or utilised in any form or by any electronic, mechanical, or other means, now known or hereafter invented, including photocopying and recording, or in any information storage or retrieval system, without permission in writing from the publishers.

\section{Notice:}

Product or corporate names may be trademarks or registered trademarks, and are used only for identification and explanation without intent to infringe.

Library of Congress Catalog Number: 2016026180

Library of Congress Cataloging-in-Publication Data

Names: Stebbins, Robert A., 1938- author.

Title: Leisure activities in context : a micro-macro/agency-structure interpretation of leisure / Robert A. Stebbins.

Description: New Brunswick, New Jersey : Transaction Publishers, 2016. | Includes bibliographical references and index.

Identifiers: LCCN 2016026180 (print) | LCCN 2016046501 (ebook) | ISBN 9781412864121 (hardcover : acid-free paper) | ISBN 9781412863766 (ebook) | ISBN 9781412863766

Subjects: LCSH: Leisure--Sociological aspects.

Classification: LCC GV14.45 .S833 2016 (print) | LCC GV14.45 (ebook) | DDC 306.4/812--dc23

LC record available at https://lccn.loc.gov/2016026180

ISBN 13: 978-1-4128-6412-1 (hbk) 
To Chris Rojek 

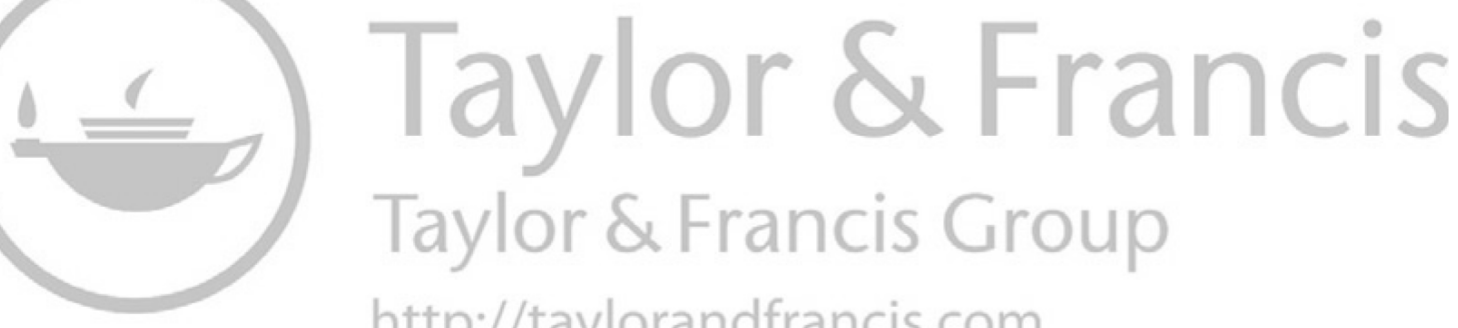
http://taylorandfrancis.com 


\section{Contents}

Acknowledgments $\quad$ ix

Introduction $\quad$ xi

1. Studying the Contexts of Leisure: Basic Concepts 1

2. Three Domains 25

3. The Meso Context 43

4. Formal Organizations: Macro Context 63

5. Noninstitutionalized Macro Context:

Social Movements and Tribes $\quad 77$

6. Temporal Context $\quad 89$

7. Geographical Context 103

8. Historical Context 119

9. Deviant Leisure Interests and Social Issues 139

10. Conclusions 157

$\begin{array}{ll}\text { Bibliography } & 165\end{array}$

$\begin{array}{ll}\text { Index } & 179\end{array}$ 

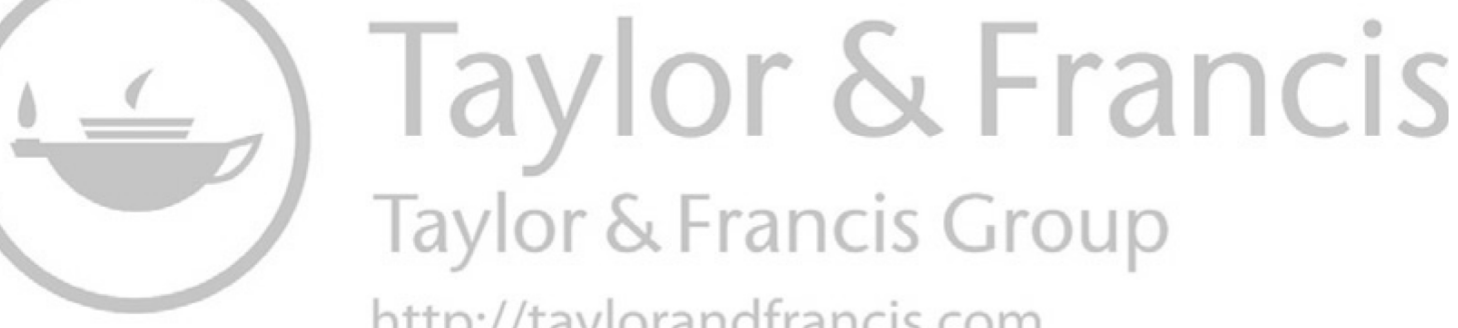
http://taylorandfrancis.com 


\section{Acknowledgments}

Chris Rojek and I have been seen by many of our colleagues in leisure studies as representing, respectively, the macro/structural and micro/ agency poles of theory in that field. In fact, both of us have occasionally strayed into the other's presumed theoretic territory, as when Chris discusses "intentionality" and I write about the organizational and historical bases of various leisure activities. As for me, it was in reading over the years a number his books and articles that I began to consistently see leisure in macro structural terms as well as continuing to see it at the micro and meso levels, in harmony with my initial formation in symbolic interactionism. This book is, among things, an attempt to bring us together intellectually, which I believe Chris will appreciate, even if he, guided by the same goal, would probably execute this link differently.

My editors at Transaction have always been first-rate. Caroline Russomanno has, with this book, certainly kept up that tradition. Many thanks! 

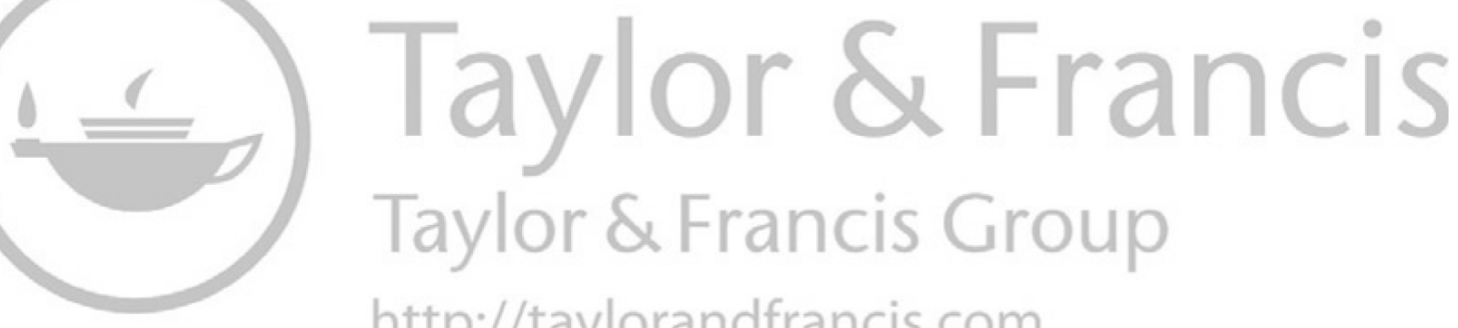
http://taylorandfrancis.com 


\section{Introduction}

I have been arguing in recent years-since Stebbins (2009a) to be precise-that serious, casual, and project-based leisure, while they can be partly explained as activities that offer their participants either enjoyable or fulfilling experiences, can also be substantially explained by the social, historical, cultural, temporal, and geographical contexts in which they are pursued. This is, of course, a leisure studies version of the time worn, social science concern about the explanatory dominance of micro vis-à-vis macro level theory and related research, known in theoretical circles as the micro-macro/agency-structure debate. The word context-my preferred summary term for the micro-macro/ agency-structure levels of phenomena-includes a variety of collective formations, many of which unfortunately are commonly given short shrift in the diverse abstract arguments about context. These formations are the social worlds, formal organizations, social institutions, spatial arrangements, social movements, and global postmodern tribes that characterize modern social life. By contrast, certain other meso and macro level phenomena have been much more fully examined. In leisure studies they include statements about leisure trends (e.g., Rojek and Blackshaw), historical changes in leisure (e.g., Spracklen, Cross, and Gelber), cultural practices as leisure (e.g., Chick, Rojek, and Roberts), and some of the social problems generated from time to time by the search for leisure (e.g., inequality of leisure opportunity, deviant leisure, unhealthy leisure practices, and annoying leisure activities).

Intrapersonal, interpersonal, and structural leisure constraints fit in this contextual analysis in distinctive ways ${ }^{1}$. As discussed more thoroughly in Chapter 1, leisure constraints inhibit choice of or participation in particular leisure activities. Structural constraints are associated with, for example, race, gender, religion, social class, and the availability of financial resources. Interpersonal constraints spring up in, for instance, dyadic, interactive, and small-group situations. The intrapersonal variety is evident in, among others, belief, attitude, 
and psychological conflict. Nevertheless, this distinction can be fuzzy, especially when constraint and context refer to the same condition or situation. And speaking of conceptual fuzziness here we also find leisure facilitators, where it can happen that one person's facilitator is another's constraint.

In other words, my intention is to present the big picture of leisure, with big picture being defined in Webster's Collegiate Dictionary $\left(11^{\text {th }}\right.$ ed.) as the "entire perspective on a situation or issue." Big pictures do not, at least should not, ignore the component elements of which they are comprised, which in the present volume, means I must also devote sufficient attention to the micro/agency part of the portrait to show how it fits there. Nonetheless, this book is dominantly about the meso- and macro-structural parts of the big picture that frame leisure activity and experience. These two parts are thinly and unevenly discussed in the leisure studies literature.

By and large this book reports no new (heretofore unpublished) research data. Rather, it is primarily a theoretic undertaking, wherein I aim to show how both leisure as free-time activity and a sample of the existing leisure studies literature can be fruitfully understood in a new light, namely, that of context. Using this big-picture approach, I want to explain leisure in a broad, holistic manner, something never attempted on this scale. That is, there have been any number of micro, meso, and macro analyses of leisure, but never to my knowledge has anyone tried to show how these three levels of context fit together in that domain. To this end, some special concepts appear in this new picture: context, embeddedness (Jonathan Turner's concept), constraints and facilitators, and incorporation and linking (for the latter two, see especially Chapters 3 and 10). My hope is that every reader of this book will come to see each instance of leisure behavior or activity in the big contextual picture painted here rather than viewing it only on one level (e.g., micro context). ${ }^{2}$

In all this, I make no claim to solving the micro-macro question. Yet the following pages do show that the past 40 some years of research and theory on leisure have shed considerable light on its context at all levels and on the ways that participants are embedded within them. This, however, constitutes a micro-to-macro analysis of only one part of society. However, perhaps this is the road to travel; to examine in much greater detail one segment of a society rather than attempting to examine all its segments at once. The latter approach seems to have 
become in the present a formidable stumbling block for such thinking. In short, the approach set out in this book shows how a rich micromacro/agency-structure analysis can be carried out using the leisure studies literature as a model (discussion continued in Chapter 10).

A set of basic concepts will guide this examination of the context of leisure. They are introduced in Chapter1: leisure, leisure as activity, self-efficacy and personal agency, agency vis-à-vis structure, satisfaction vis-à-vis fulfillment, the macro-micro/agency-structure debate, constraints and facilitators, and the serious leisure perspective. A main goal in this undertaking is, when talking about structure, not to lose sight of the importance of agency.

Each chapter after Chapter 1 presents a distinctive contextual point of view. Some of these points of view are common fare in the agency-structure debate, namely, institutions (Chapter 2), large-scale organizations (Chapter 3), and history (Chapter 8 ). They have also been explored in leisure studies, though unevenly so. The points of view considered in Chapters 4 through 7 and Chapter 9 are more weakly represented, if represented at all, in the agency-structure literature, while social world (Chapter 4), temporal context (Chapter 6), and geographic context (Chapter 7) are lively contextual interests in leisure studies. Social movements (Chapter 5) and deviance and social issues (Chapter 9) have been only sporadically addressed in both fields. The aforementioned basic concepts organize discussion throughout this part of the book.

The present study of context has turned out to be an exceedingly complex matter, even if limited to only one part of society, namely, the one of leisure. To help obviate getting lost among the trees in this forest of ideas and data, I will identify from time to time different theoretic waypoints called "key points." Their object is to link the discussion of the moment with the leisure contexts, constituting thereby a kind of summary statement of that discussion and its original import. Each chapter's key statements will also be listed in its conclusions.

These statements, regarded as a unit, constitute some of the conceptual glue that joins the micro and macro poles. We will see that this is often accomplished at the meso level. It is at this level that the embeddedness that Jonathan Turner (2005) finds lacking in the agency-structure discourse (see Chapter 1 ) is especially critical in getting from micro to macro and from macro to micro. However, first, let us look at the basic concepts on which this book is based. 


\section{Notes}

1. The field of leisure constraints has a long history (Jackson, 2005, Chapter 1).

2. I am not proposing that every empirical study of or theoretic treatise on leisure fully address the big picture. The proposal is simply that specialists in this field become aware of it as it bears on their object of research or analysis, to the point of noting however briefly in reports of it where their smaller-picture efforts fit in the bigger canvas. Admittedly, I have in the past been guilty in failing to do this. 


\section{1}

\section{Studying the Contexts of Leisure: Basic Concepts}

The main goal of this book is to place the personal experience of leisure participation in the broader frame of the micro-, meso-, and macro-contexts in which leisure is pursued. I want to show how that experience is shaped by those contexts and how the contexts are shaped by the leisure experiences and the parallel agency of participants in leisure activities. In the present chapter, we look at the basic concepts needed for an effective study of the contexts of leisure. These include a definition of leisure, which is followed by a discussion of the centrality of activity, personal agency, and self-efficacy. The rewards of satisfaction and fulfillment are considered next, with this leading to the macro- or micro/structure-agency debate and on to leisure constraints and facilitators. The chapter closes with a précis of the serious leisure perspective (SLP). Culture is also a basic concept, but one so broad that is it is best discussed in conjunction with the various contextual points of view of which it is an important part.

\section{Defining Leisure}

The definition of leisure presented below is intended to bridge the individual and contextual approaches, with both being equally important in defining leisure. From these two angles, leisure is both seen and experienced by the individual participant and seen as embedded in the wider social, cultural, historical, and geographical world. Earlier I tackled the problem of defining leisure from these two angles (Stebbins, 2012). A condensed, dictionary-style definition of leisure emerged from that undertaking: uncoerced, contextually framed activity engaged in during free time, which people want to do and, using their abilities and 
resources, actually do in either a satisfying or a fulfilling way (or both) (modified from Stebbins, 2005a, and subsequent publications). " "Free time" in this book (it is further defined in Chapter 6 and in Stebbins, 2012, Chapter. 2) is time away from unpleasant, or disagreeable, obligation, with pleasant obligation being treated of here as essentially leisure. In other words Homo otiosus, leisure man (Stebbins, 2013a), feels no significant coercion to enact the activity in question. Some kinds of work-described later as "devotee work" - can be conceived of as pleasant obligation, in that such workers though they must make a living performing their work, do this in a highly intrinsically appealing pursuit. Work of this sort is also essentially leisure, and will be treated of as such in this book. This definition is compatible with the SLP, particularly since the latter stresses human agency, or "intentionality" (Rojek, 2010, p. 6)-what "people want to do"-and distinguishes the satisfaction gained from casual leisure vis-à-vis the fulfilment flowing from the serious form.

Note that reference to "free choice"-a long-standing component of standard definitions of leisure-is for reasons discussed more fully elsewhere (Stebbins, 2005a), deliberately omitted from this definition. Generally put, choice is never wholly free, but rather hedged about with all sorts of contextual conditions. This situation renders this concept and allied ones, such as freedom and state of mind useless as essential elements of a basic definition (Juniu \& Henderson, 2001). Note, too, that there is no reference in this definition to the moral basis of leisure as being one of its distinguishing features. In other words, contrary to some claims made in the past (e.g., Kaplan, 1960, pp. 22-25), leisure according to the SLP may be either deviant or nondeviant (see Chapter 9 of the present volume).

Uncoerced, people in leisure believe they are doing something they are not pushed to do, something they are not disagreeably obliged to do. In this definition, emphasis is ipso facto on the positive side of life, the acting individual, and the play of human agency. This in no way denies that there may be things people want to do but cannot do because of any number of constraints on choice, because of limiting social and personal conditions; for example, aptitude, ability, socialized leisure tastes, knowledge of available activities, and accessibility of activities. In other words, when using this definition of leisure, whose central ingredient is lack of coercion, we must be sure to understand leisure activities in relation to their larger personal, structural, cultural, and historical background, their context. In addition, it follows 
that leisure is not really freely chosen, as some observers have argued (e.g., Parker, 1983, pp. 8-9; Kelly, 1990, p. 7), since choice of activity is significantly shaped by this context.

Nor may free time, as conventionally defined, be treated of here as synonymous with leisure. We can be bored in our free time, which can result from inactivity ("nothing to do") or from activity, which alas, is uninteresting, unstimulating. The same can, of course, happen at work and in obligated non-work settings. Since boredom is decidedly a negative state of mind, it can be argued that, logically, it is not leisure at all. For leisure is typically conceived of as a positive mindset, composed of, among other sentiments, pleasant expectations and recollections of activities and situations. Of course, it happens at times that expectations turn out to be unrealistic, and we get bored (or perhaps angry, frightened, or embarrassed) with the activity in question, transforming it in our view into something quite other than leisure. In addition, all this may happen in free time, which exemplifies well how such time can occupy a broader area of life than leisure, which is nested within it (Stebbins, 2003).

\section{Leisure as Activity}

Our condensed definition refers to "uncoerced activity" An activity is a type of pursuit, wherein participants in it mentally or physically (often both) think or do something, motivated by the hope of achieving a desired end. Life is filled with activities, both pleasant and unpleasant: sleeping, mowing the lawn, taking the train to work, having a tooth filled, eating lunch, playing tennis matches, running a meeting, and on and on. Activities, as this list illustrates, may be categorized as work, leisure, or non-work obligation. They are, furthermore, general. In some instances, they refer to the behavioral side of recognizable roles, for example commuter, tennis player, and chair of a meeting. In others we may recognize the activity, but not conceive of it so formally as a role, exemplified in someone sleeping, mowing a lawn, or eating lunch (not as patron in a restaurant).

The concept of activity is an abstraction, and as such, one broader than that of role. In other words, roles are associated with particular statuses, or positions, in society, whereas with activities, some are status based, while others are not. For instance, sleeper is not a status, even if sleeping is an activity. It is likewise with lawn mower (person). Sociologists, anthropologists, and psychologists tend to see social relations in terms of roles, and as a result, overlook activities whether 
aligned with a role or not. Meanwhile certain important parts of life consist of engaging in activities not recognized as roles. Where would many of us be could we not routinely sleep or eat lunch?

Moreover, another dimension separates role and activity, namely, that of statics and dynamics. Roles are static whereas activities are dynamic. ${ }^{2}$ Roles, classically conceived of, are relatively inactive expectations for behavior, whereas in activities, people are actually behaving, mentally or physically thinking or doing things to achieve certain ends. This dynamic quality provides a powerful explanatory link between an activity and a person's motivation to participate in it. Nevertheless, the idea of role is useful, since participants do encounter role expectations in certain activities (e.g., those in sport, work, and volunteering). Although the concept of activity does not include these expectations, in its dynamism, it can, much more effectively than role, account for invention and human agency.

Both concepts are critical in this book, which leads to our first key point: roles and activities link the individual with certain structural aspects of the meso (more fully explained in Chapter 3) and macro contexts in which the roles and activities are carried out. In fact, roles and activities, as will become evident in later chapters, are often central points of operation for groups, organizations, social movements, and the like. Furthermore, both concepts are linchpins linking the social individual with his internal psychology, with his personality, motivation, attitudes, emotions, and so on. This book moves more deeply into the social and away from the psychological, but the importance of the latter in explaining human behavior cannot be overestimated. Moreover, it is a vital part of the SLP (see Stebbins, 2007/2015; 2009a).

This definition of activity gets further refined in the concept of core activity: a distinctive set of interrelated actions or steps that must be followed to achieve the outcome or product that a participant seeks. As with general activities, core activities are pursued in work, leisure, and non-work obligation. Consider some examples in serious leisure: a core activity of alpine skiing is descending snow-covered slopes, in cabinet making it is shaping and finishing wood, and in volunteer fire-fighting is putting out blazes and rescuing people from them. In each case, the participant takes several interrelated steps to successfully ski downhill, make a cabinet, or rescue someone. In casual leisure core activities, which are much less complex than in serious leisure, are exemplified in the actions required to hold sociable conversations with friends, savor beautiful scenery, and offer simple volunteer services (e.g., handing out 
leaflets, directing traffic in a theater parking lot, or clearing snow off the neighborhood hockey rink). Work-related core activities are seen in, for instance, the actions of a surgeon during an operation or the improvisations on a melody by a jazz clarinettist. The core activity in mowing a lawn (non-work obligation) is pushing or riding the mower. Executing an attractive core activity and its component steps and actions is a main feature drawing participants to the general activity encompassing it, because this core directly enables them to reach a cherished goal. It is the opposite for disagreeable core activities. In short, the core activity has motivational value of its own, even if more strongly held for some activities than others and even if some activities are disagreeable, but still have to be done.

Core activities can be classified as simple or complex, the two concepts finding their place at opposite poles of a continuum. The location of a core activity on this continuum partially explains its appeal or lack thereof. Most casual leisure is comprised of a set of simple core activities. Here Homo otiosus need only turn on the television set, observe the scenery, drink the glass of wine (no oenophile is he), or gossip about someone. Complexity in casual leisure increases slightly when playing a board game using dice, participating in a Hash House Harrier treasure hunt, or serving as a casual volunteer by, say, collecting bottles for the Scouts or making tea and coffee after a religious service. In addition, Harrison's (2001) study of upper-middle-class Canadian mass tourists revealed a certain level of complexity in their sensual experience of the touristic sites they visited. For people craving the simple things in life, this is the kind of leisure to head for. The other two domains abound with equivalent simple core activities, as in the work of a parking lot attendant (receiving cash/making change) or the efforts of a householder whose non-work obligation of the day is raking leaves.

So, if complexity is what people want, they must look elsewhere. Leisure projects are necessarily more complex than casual leisure activities. The types of projects listed later in this chapter provide, I believe, ample proof of that. Nonetheless, they are not nearly as complex as the core activities around which serious leisure revolves. The accumulated knowledge, skill, training, and experience of, for instance, the amateur trumpet player, hobbyist stamp collector, and volunteer emergency medical worker are vast, and defy full description of how they are applied during conduct of the core activity. Of course, neophytes in the serious leisure activities lack these acquisitions, though it is unquestionably their intention to acquire them to a level where they 
will feel fulfilled. As with simple core activities, complex equivalents also exist in the other two domains. Examples in work include the two earlier examples of the surgeon and the jazz clarinettist. In the nonwork domain, two common examples demonstrate a noticeable level of complexity: driving in city traffic and for some people, preparing the annual income tax return.

Activity as just defined is, by and large, a foreign idea in psychology, anthropology, and sociology. Sure, scholars there sometimes talk about, for instance, criminal, political, or economic activity, but in so doing, they are referring, in general terms, to a broad category of behavior, not a particular set of actions comprising a pursuit. Instead, our positive concept of activity knows its greatest currency in the interdisciplinary fields of leisure studies and physical education and, more recently, kinesiology. In addition, I suspect that the first adopted the idea from the second. There has always been, in physical education, discussion of and research on activities promoting conditioning, exercise, outdoor interests, human movement, and so on.

\section{Self-Efficacy and Personal Agency}

Self-efficacy and personal agency are two main avenues leading to fulfillment. Psychologist Albert Bandura pioneered the concept of self-efficacy, defining it as "people's beliefs in their capabilities to produce desired effects by their own actions" (Bandura, 1997, p. vii). He argued that people develop "efficacy expectations" bearing on particular goals they hope to realize and on what they must do to achieve this. These expectations are based on the capabilities individuals believe they have to accomplish the goals they are pursuing in a particular setting. Bandura says that efficacy expectations constitute the cognitive state immediately preceding goal-directed actions. Additionally efficacy is enhanced to the extent that people's locus of control is high; in other words they sense that their activities result from their own efforts rather than from such impersonal forces as fate, luck, and chance (Rotter, 1990).

A principal interest in this book can be expressed as the second key point: belief in one's own micro-contextual self-efficacy is necessary to pursue in a fulfilling way at the meso and macro levels particular activities in serious leisure or devotee work. This belief in oneself is born of the numerous routine successes that accumulate with the enduring, systematic pursuit of an activity. Encouragement from others who also partake of it or who are otherwise close associates of the participant is another source of such efficacy. 
In leisure studies, personal agency is both a social arrangement for enabling and a personal capacity for putting into effect what an individual intends to do. The individual thus enabled (not constrained) by society can become his own agent in producing the intended outcome. Here agency refers to seizing the initiative to reach a goal, short or long term. It includes figuring out how to reach the goal, which includes organizing to this end oneself and such relevant other entities as individuals, organizations, groups, and social networks. Agency rests on the participant's sense of self-efficacy and control in planning, organizing, working with others, and so on. Thus, a concert violinist can only perform her concerto when accompanied by an orchestra guided by its conductor, a quarterback in American football cannot express his agency as a passer unless there is a teammate downfield trying to catch the ball that person is passing. Agency is also at work when a participant arranges for necessary resources.

It is through particular activities that people, propelled by their own agency and belief in their own efficacy, find positive things in life, which they blend and balance with the negative, or disagreeably obligatory, things they must also deal with Un-coerced, people in leisure believe they are doing something they are not pushed to do, something they are not disagreeably obliged to do. In this definition, emphasis is ipso facto on acting individuals and on their self-direction through personal agency.

\section{Agency and Structure}

Given the scope of this book, a few words on personal agency and its relationship to social structure are in order. Martin Hewson (2010, p. 13) says of agency: "it is the condition of activity rather than passivity. It refers to the experience of acting, doing things, making things happen, exerting power, being a subject of events, or controlling things. This is one aspect of human experience." His conceptualization of agency is designed to set it within sociology's long-standing debate on the freedom of human behavior as agency $v i s-\grave{a}$-vis the limits imposed on it by social structure (e.g., Giddens, 1986). Hewson's definition is of necessity quite general; agency is viewed broadly as a condition of activity as opposed to passivity.

Agency conceived of in leisure studies revolves around a different and more specific theoretic interest, namely, explaining how people fired by their own initiative pursue, or fail to pursue, particular free-time activities (Stebbins, 2009, pp. 4-6). ${ }^{3}$ They are not only active but also 
intent on doing something, in this book pursuing leisure. The definition of activity used throughout this book therefore diverges from Hewson's as he relates it to passivity, where this state is forced on a society's members by its social structure. Chris Rojek (2010, pp. 6-9), by the way, explores this relationship under the heading of "intentionality", doing so from the unconventional angle of leisure studies. Intentionality is basically the same as agency, and taking leisure is a main expression of it, albeit as we will see later, within certain structural confines.

\section{Satisfaction, Fulfillment, Etc.}

Both as researchers on leisure and as participants in everyday life, we hear it all the time: "I sure had fun last night at the football game"; "It will be a fun time at Joan's sleepover"; "it was a most enjoyable evening" (said to the host). Much less often do we hear leisure experiences being described as satisfying or fulfilling, even if, for their participants, some experiences have precisely that quality. Why these differences in choice of descriptors for positive leisure experience, and what do these four descriptors mean in science and common sense?

Common sense usage of the four, as typical of common sense everywhere, is rather loose and for the first two broadly applied. Thus, the adjective "fun" usually denotes finding pleasure or amusement in a particular activity, while the adjective "enjoyable" typically refers to an activity that can be enjoyed, that gives pleasure or delight. In other words, these two descriptors are basically synonyms. Turning to the third term, a satisfying experience, in one sense of the word, is itself synonymous with an experience that is fun or enjoyable (sometimes referred to as gratifying). However, another sense of this adjective is substantially different: it refers to meeting or satisfying a need or want. Put otherwise, a satisfying experience in this second sense leads to contentment with reference to a particular need or want, an additional meaning that sets it apart from the other three descriptors. By contrast, the fourth term, in one sense, points to a fulfilling experience, or more precisely, to a set of chronological experiences leading to development to the fullest of a person's gifts and character, to development of that person's full potential. A second sense of this adjective is, however, synonymous with the second sense of satisfying.

These four descriptors form a rough scale of depth of leisure experience, running from that which is superficial-fun-to that which is profound-fulfillment. In common sense usage we seem, in crude fashion, to recognize these differences, in that, for example, few people 
would describe a sleepover as fulfilling or a grueling marathon as fun or enjoyable. The task of leisure science and this section is to recognize the existence of this implicit, common sense scale of leisure experience, while for scientific purposes, to try to iron out vagueness and inconsistency as these plague everyday usage of the four terms. We turn first to fun.

Because of the dual meaning of satisfaction, I have found it necessary, when striving to be as clear as possible about the rewards of serious leisure, to rely exclusively on the concept of fulfillment. It is substantially different from satisfaction, even in the second sense of the word. Serious leisure leads to satisfying achievement and accomplishment, of that there is no doubt, but it is also leads to personal development and self-confidence, to maximizing one's gifts and character through the pursuit of particular leisure activities (see Stebbins, 2004). Meanwhile, satisfaction can also mean, as noted in this section, becoming content or being content through gratification or pleasure experienced in an activity, which may well be of the casual leisure variety.

To avoid this confusion when talking about the rewards of the serious pursuits, it has become necessary to frame discussion in the less ambiguous language of fulfillment rather than the more ambiguous language of satisfaction. The latter is a slippery concept, primarily because it is cursed with two quite different meanings. Moreover, experiencing achievement (the second meaning) is not really the same as experiencing fulfillment. For the latter rests on a clear sense of a "formative career" (Stebbins, 2009, pp. 68-69) in a complex role (found in work, leisure, a relationship, etc.), on the sense of realizing one's gifts and character over many years. Achievement, by contrast, results from a particular effort at a particular time in life. Thus fulfillment is, among several other things, a series of interrelated achievements across a span of time that the achiever sees as manifesting his or her potential.

Be that as it may, serious leisure enthusiasts do, at times, qualify their activities as fun. I have tried to deal with this seeming anomaly by invoking the idea of gratification. Over the years I have come to describe as gratifying an activity that the participant sees as fun, but that also generates fulfillment. For instance, some of the kayakers in the Canadian Rockies whom we interviewed and who possessed the appropriate skills and experience said it is "fun" to paddle Class-4 Rivers. By this, they meant that the activity is gratifying, because over time, they have acquired the technical qualifications to carry it off with relative ease (Stebbins, 2005b). This level of activity is fun, precisely because it 
is technically difficult but nonetheless quite manageable (it is fulfilling), given the participant's high level of development in the hobby.

In technical activities of this sort, fun has also been said to be a significant component of the flow experience, as seen in Csikszentmihalyi's (1990, pp. 49, 72) linking of enjoyment with flow. But more recent thought on the matter by Seligman and Csikszentmihalyi (2000, p. 12) has led them to distinguish between the "pleasure" of what we have been calling fun (in casual leisure) from the "enjoyment" of activities referred to in this book as the serious pursuits. In this newer conceptualization, enjoyment and self-fulfillment amount to the same thing.

Mannell and Kleiber (1997, pp. 185-186) treat satisfaction in terms consistent with the second sense of the term described earlier: the activity in question is satisfying when it meets needs or motives, leading thus to contentment and, where appropriate, a sense of achievement. The authors then go on to link the pursuit of satisfaction in free time with leisure motivation. Note that some of the needs satisfied by leisure activity are ones related to achievement and accomplishment-even if, as Shaw (1985) found, such satisfaction is only a minor dimension of the popular meaning of leisure.

Mannell and Kleiber's observation that the pursuit of satisfaction in free time is, at bottom, a matter of leisure motivation brings us back to this book's leitmotif. It is while searching for fun, enjoyment, satisfaction, and fulfillment that Homo otiosus is drawn to particular leisure and work activities, which are however, always embedded in a larger sociocultural, historical, spatial context. In harmony with what was said earlier, to understand fully the appeal of these activities, we must also view them in this context. Chapters 2 through 9 show what this means in the daily life of the leisure participant.

\section{The Macro-Micro/Agency-Structure Debate}

One context that has only been alluded to so far in this chapter is the intellectual context underlying the preceding section on self-efficacy and agency, namely the macro-micro debate. Sociologists are particularly interested in this question, even though it is germane to all the social sciences. Jonathan Turner (2005, p. 405) describes it:

At the heart of the issue is how explanations of population-level or societal-level phenomena are to be reconciled with explanations about behavior and interpersonal processes. Once this 
turn is taken, the problems of linking the macro and micro, or of filling the micro-macro "gap," become ever more salient.

We have treated of this gap in this book as agency versus structure, which Turner points out is the preferred language for micro and macro among the European thinkers on the matter (e.g., Archer, 1988; Giddens, 1986).

Turner (2005) identifies the problem that has been troubling analysis in this area of thought, notably, the vagueness of its theories:

Those arguing for the primacy of human agency typically want to see humans as having some degree of free will, whereas those pushing the more structural side will tend to see human action as highly circumscribed by cultural and structural parameters. There is nothing inherently contradictory about these two positions, since human action can be constrained without being determined, while structures can be reconstituted by acts of individuals. But, simply saying this does not explain anything; and when the agency-structure question is conflated with the micro-macro issues, theories are typically rather vague (p. 406)

Most of Turner's chapter consists of a review of the multiple attempts to solve this problem. All are very general, he maintains, leaving out of consideration important specifics that can explain how the micro, meso, and macro levels of society are interrelated.

Turner's own answers to the micro-macro/agency-structure question come close to the aims of this book and the third key point: To understand leisure we must recognize that the domain of leisure also consists of these three levels. Over the years Homo otiosus has created a wide variety of arrangements (e.g., organizations, social worlds, and subcultures) to meet his leisure needs and interests. Furthermore, there is considerable "embeddedness" (Turner's term) in these arrangements. For example, leisure participants fit into their surrounding social worlds, they form organizations some of which may spawn national or international federations, and they go in for activities that reflect certain values of the day (e.g., the modern interest in adventure, physical fitness, individuality). All this is real to these people-the three levels, the groups and organizations, the values, and more-though of course, they would usually use different terms to describe them and be rather vaguer than we are here about their conceptualization. 
Let me be clear: I make no claim to solving or even trying to solve the micro-macro question. Yet, the following pages do show that the past 45 years of research and theory on leisure have shed considerable light on its context at all levels and on how participants are embedded within them. This, however, constitutes a micro-macro analysis of only one part of society. However, perhaps this is the route to follow; to examine in much greater detail one segment of a society rather than attempting to examine all its segments at once. The latter approach seems to have become in the present a formidable stumbling block for such thinking.

\section{Constraints and Facilitators}

Earlier, Turner mentioned that human action "can be constrained." There exists in leisure studies a strong interest in leisure constraints. David Scott (2003, p. 75) defines them as "factors that limit people's participation in leisure activities, use of services, and satisfaction or enjoyment of current activities." Interest in this aspect of leisure dates to the 1980s, with sporadic work in the area having been conducted even earlier (see Jackson \& Scott, 1999, pp. 300-302). Thus, thought and research about the "barriers" (as constraints were initially labelled) to personal agency are well entrenched in leisure studies. Constraint is the better term here, for a constraint can sometimes be overcome, whereas a barrier suggests that this is impossible (Crawford, Jackson, \& Godbey, 1991).

The first two categories of constraints-intrapersonal and interpersonal-would not commonly stir much interest among the scholars caught up in the micro-micro/agency-structure debate, whereas the third category-structural constraints-most certainly would. The intrapersonal constraints are bodily conditions and psychological states, such as attitudes and personality that discourage taking up particular leisure activities. At the interpersonal level, constraints emerge in social interaction, typically that occurring within family and friendship circles. Such processes as coach's favoritism, scheduling of rehearsals, and screening of group members are included under this heading.

Scott observed that structural constraints are the most theoretically "integrated and documented" of the three types. They emanate from conditions beyond the control of the participant. One can be structurally constrained by family requirements, stage of life, availability and knowledge of opportunities, and the like. In general, the field of leisure 
constraints has amassed over the years an admirable range and depth of research (see Jackson, 2005).

\section{Facilitating Leisure}

According to Raymore (2002) facilitators to leisure are "factors that are assumed by researchers and perceived or experienced by individuals to enable or promote the formation of leisure preferences and to encourage or enhance participation" (p. 39). This definition is an adaptation of Jackson's definition of constraint, where facilitator is seen (by Raymore) as its antonym. Nevertheless, the two are not polar opposites, since facilitation is not necessarily achieved by overcoming one or more constraints or even achieved because of their absence. Writing on the relationship of facilitators and constraints to leisure motivation, Raymore argued that "the facilitator is the condition itself, not the process through which that condition energizes or motivates behavior leading to (i.e., facilitating) or limiting (i.e., constraining) participation" (pp. 43-44). He follows up this observation by linking constraints and facilitators to the expectancy-value theory of achievement motivation. Raymore wrote on facilitation, because he believed that the popularity of constraints as an object of research was creating an imbalance relative to their importance in a full explanation of leisure participation.

In this conceptualization, facilitators may be regarded as resources for leisure activities. Furthermore, as with constraints, facilitators may be intrapersonal, interpersonal, and structural. Raymore theorizes that intrapersonal facilitators are individual characteristics, traits, and beliefs that enable or promote the development of leisure preferences and that encourage or enhance leisure participation. The interpersonal facilitators, which originate in other people or groups of people, have similar effects. It is likewise with structural facilitators; they are found in social and physical institutions, organisations, and belief systems.

Inherited characteristics constitute an important class of intrapersonal facilitators. For example, being endowed with exceptional muscular strength, vocal clarity, or facial beauty enhances success in rugby, operatic singing, or fashion modeling, respectively. Knowing the coach, being a member of an outstanding musical group, or working in an electronics shop may facilitate on an interpersonal basis getting invited to join a football team, experiencing top honors in a chamber music context, or having access at discounted prices to computer equipment. Structurally an individual's participation in a leisure activity may 
be facilitated by membership in an amateur science society or fishing club with exclusive use of a private pond or by adherence to a religion that allows the faithful access to a retreat.

Both constraints and facilitators limit choice. But otherwise, the two have remarkably different effects on the pursuit of leisure. First, constraints are negative; they hinder leisure choice. Second facilitators, like leisure itself, are positive; they enable people to pursue what they want to do. Yet, that facilitators limit choice is usually of rather little consequence for the participant. As the foregoing illustrations suggest there is much of the time little incentive to abandon an activity that is well facilitated for another which lacks in significant measure this resource. More precisely facilitators are conditions that help motivate people to take up an activity and stay with it. At this point, the activity in question is in the process of being chosen or has been chosen and is now being actively pursued, however limited the antecedent range of choices shaped by a diversity of constraints. Some of these constraints are highly restrictive, for depending on the society, some members may be denied the right to pursue a fair assortment of leisure activities. For example, Martin and Mason (2004) report that, among devout female Muslims, sport, and physical recreation, though acceptable, may only be pursued according to the precepts of Islamic modesty and dress. In addition, in all societies knowledge of the full range activities to which the individual does have a right is rarely complete.

This discussion of constraints and facilitators leads to our fourth key point: context whatever its level includes negative and positive constraints and facilitators. Moreover, the foregoing ideas suggest that choice of activities, to the extent that people have choices, is guided not only by what is available to them but also by what the chooser (1) can do acceptably well at, (2) find sufficient resources for, and (3) receive some encouragement in. This is why we must consider these two concepts together. If nothing else we need much more research on facilitation, which is so far very thin. ${ }^{4}$ One danger in ignoring facilitation and failing to look at the two ideas together lies in overstressing the role of constraints in the sole domain in life where positiveness reigns (for a discussion of leisure as positive, see Stebbins, 2009a).

Concerning the three types of leisure constraints, are they not on the structural and cultural levels merely free-time manifestations of restrictive macro-context? The answer is generally no. Leisure constraints are particular cultural and structural forces inhibiting leisure choice. In contrast, context as discussed in this book is much broader. 
As stated in the Introduction, the concept includes social worlds, formal organizations, social institutions, spatial arrangements, and social movements. It also includes leisure trends and leisure history, cultural practices and the social problems engendered by the search for leisure. Nonetheless, the leisure contexts do contain some constraints, as well, which when appropriate, will be duly noted in the following pages.

\section{The Serious Leisure Perspective}

It has been my practice in earlier publications to present the SLP in as much detail as possible, based on the assumption that some readers would be unfamiliar with it. My colleagues have said in recent years, however, that such is no longer necessary; "we know all that, so let's get on with what's new." Thus, since they are the principal audience of this book, I have in several places accepted their advice, and present only a summary of the ideas in question accompanied by references to sources offering more complete coverage. The following presentation of the SLP is the first of these abbreviated statements.

The SLP can be described, in simplest terms, as the theoretic framework that synthesizes three main forms of leisure showing, at once, their distinctive features, similarities, and interrelationships (the SLP is discussed in detail in Stebbins, 2012; 2007/2015; 2001b; 1992). Additionally the Perspective considers how the three formsserious pursuits (serious leisure/devotee work), casual leisure, and project-based leisure-are shaped by various psychological, social, cultural, and historical conditions. Each form serves as a conceptual umbrella for a range of types of related activities. For a brief history of the Perspective, see the history page at www.seriousleisure.net or for a longer version, see Stebbins, 2007/2015, Chapter 6).

My research findings and theoretic musings over the past 40 years have nevertheless evolved and coalesced into a typological map of the world of leisure (That is, so far as known at present, all leisure (at least in Western society) can be classified according to one of the three forms and their several types and subtypes. Figure 1.1 presents a map of the typological structure of the Perspective.

\section{The Serious Pursuits}

We start with the serious leisure component of these pursuits. Amateurs are found in art, science, sport, and entertainment, where they are invariably linked in a variety of ways with professional counterparts. The two can be distinguished descriptively in that the activity 


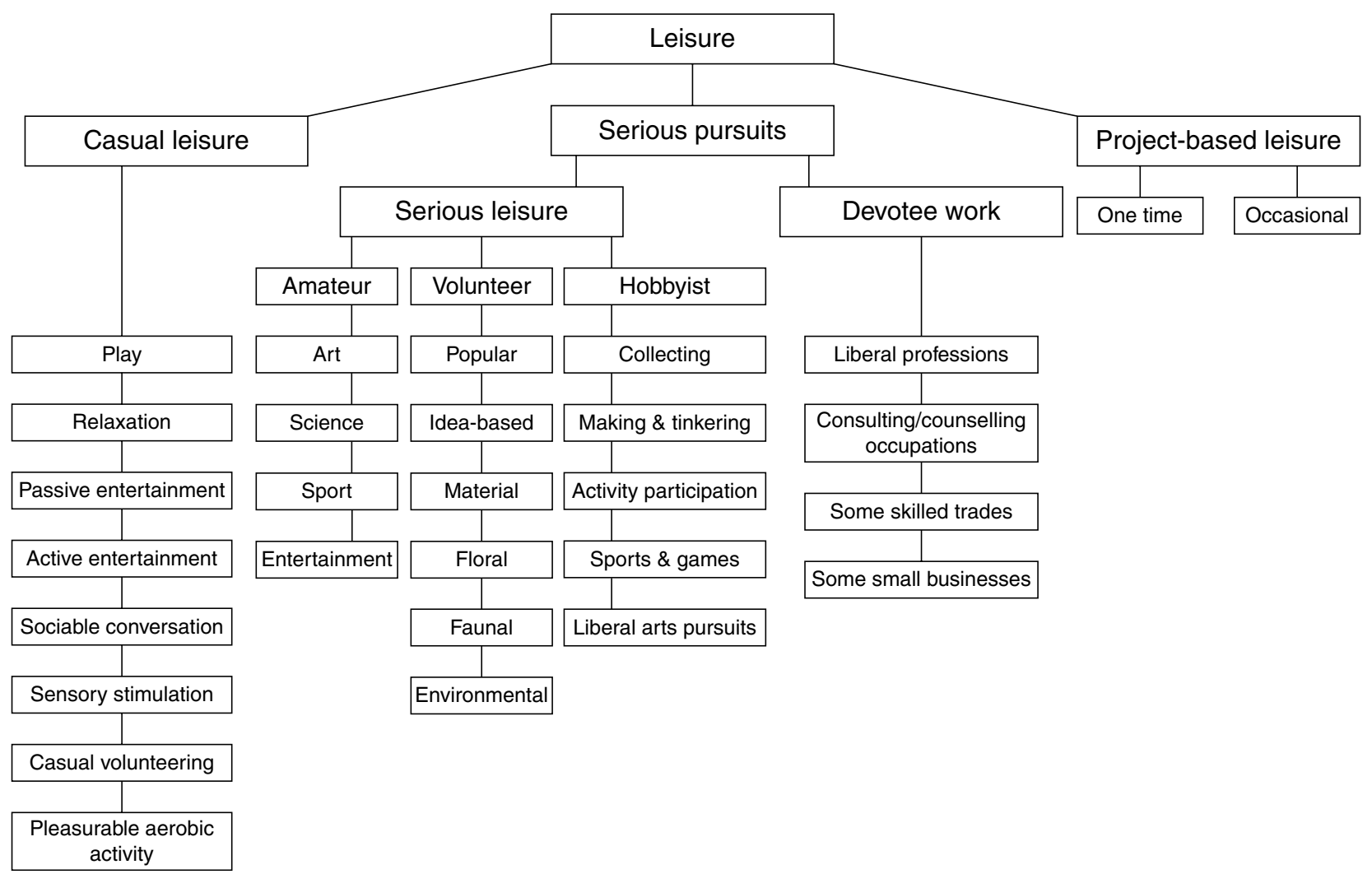

Figure 1.1. The serious leisure perspective. 


\section{References}

Aberle, D. F. (1966). The peyote religion among the Navaho. Chicago, IL: Aldine.

Agnew, J. (2011). "Space and place." In Handbook of geographical knowledge, edited by John Agnew and David N. Livingstone (pp. 316-330). London: Sage.

Aitchison, C. (2000). "Young disabled people, leisure and everyday life: Reviewing conventional definitions for leisure studies." Annals of Leisure Research, 3, 1-20.

Amis, J. , Slack, T. , \& Berrett, T. (1995). "The structural antecedents of conflict in voluntary sport organizations." Leisure Studies, 14, 1-16.

Applebaum, H. (1992). The concept of work: Ancient, medieval, and modern. Albany, NY: State University of New York Press.

Apostle, R. (1992). "Curling for cash: The "professionalization" of a popular Canadian sport." Culture, 12(2), 17-28.

Archer, M. S. (1988). Culture and agency: The place of culture in social theory. Cambridge:

Cambridge University Press.

Aronowitz, S. , \& DiFazio, W. (2010). The jobless future: Sci-tech and the dogma of work, 2nd ed. Minneapolis, MN: University of Minnesota Press.

Atkinson, M. , \& Young, K. (2005). "Reservoir dogs: Greyhound racing, mimesis and sportsrelated violence." International Review for the Sociology of Sport, 40, 335-356.

Avilés, C. (2011). "Do you see yourself playing at Carnegie Hall?" February 3.

http://tipsforclassicalmusicians.com/2011/02/03/do-you-see-yourself-playing-at-carnegie-hall, retrieved November 27, 2014.

Back, K. W. (1981). "Small groups." In M. Rosenberg , \& R.H. Turner (Eds.), Social psychology (pp. 320-343). New York: Basic Books.

Baldwin, C. K. , \& Norris, P. A. (1999). "Exploring the dimensions of serious leisure: "Love me-love my dog."' Journal of Leisure Research, 31, 1-17.

Barnes, J. A. (1954). "Class and committees in a Norwegian island parish." Human Relations, 7 , 39-58.

Bauckham, D. (2013). "Serious leisure: The case of groundhopping." In T. Blackshaw (Ed.), Routledge handbook of leisure studies (pp. 443-455). London: Routledge.

Baudrillard, J. (1998). The consumer society: Myths and structures, trans. by C. Turner .

Thousand Oaks, CA: Sage.

Beatty, J. , \& Torbert, W. R. (2013). "Yin and yang: The relationship of leisure and work." In T. Blackshaw (Ed.), Routledge handbook of leisure studies (pp. 468-480). London: Routledge.

Beck, U. , \& Beck-Gernsheim, E. (2002). Individualization: Institutionalized individualism and its social and political consequences. London: Sage.

Becker, H.S. (1963). Outsiders: Studies in the sociology of deviance. New York: Free Press. Beedie, P. (2008). "Adventure tourism as a "new frontier" in leisure." World Leisure Journal, 50(3), 173-183.

Bella, L. (1992). The Christmas Imperative: Leisure, family, and women's work. Halifax, NS: Fernwood.

Bendle, L. J. , \& Patterson, I. (2008). "Network density, centrality, and communication in a serious leisure social world." Annals of Leisure Research, 11(1 and 2), 1-19.

Bialeschki, M. D. , \& Pearce, K. D. (1997). "I don't want a lifestyle-I want a life: The effect of role negotiations on the leisure of lesbian mothers." Journal of Leisure Research, 29, 113-131.

Blackshaw, T. , \& Long, J. (1998). "A critical examination of the advantages of investigating community and leisure from a social network perspective." Leisure Studies, 17, 233-248.

Boesveld, S. (2007). "Doctor burnout hurts health care." Calgary Herald, Wednesday 3 October. Bornstein, D. , \& Davis, S. (2010). Social entrepreneurship: What everyone needs to know. New York: Oxford University Press.

Bosserman, P. , \& Gagan, R. (1972). "Leisure behavior and voluntary action." In D.H. Smith, R.D. Reddy , \& B.R. Baldwin (Eds.), Voluntary Action Research (pp. 109-126). Lexington, MA: D.C. Heath.

Bott, E. (1957). Family and social network. London, UK: Tavistock.

Bourdieu, P. (1977). Outline of a theory of practice, trans. by R. Nice . Cambridge \& New York: Cambridge University Press.

Bourdieu, P. (1979). La distinction: Critique sociale du jugement, trans. by R. Nice . Paris: Les Editions de Minuit. 
Brainard, L. A. , \& Brinkerhoff, J. (2004). "Lost in cyberspace: Shedding light on the dark matter of grassroots organizations." Nonprofit and Voluntary Sector Quarterly, 33(3, Supplement), 32S-53S.

Brattain Rogers , N. (1999). "Family obligation, caregiving, and loss of leisure: The experiences of three caregivers." Activities, Adaptation \& Aging, 24(2), 35.

Briggs, D. , \& Stebbins, R. A. (2014). "Silo ice climbing: An exploration of a new outdoor leisure activity." Journal of Outdoor Recreation, Education, and Leadership, 6(1), 55-67.

http://dx.doi.org/10.7768/1948-5123.1190

Brown, D.E. (1991). Human universals. New York: McGraw-Hill.

Bryce, J. , \& Rutter, J. (2003). "Gender dynamics and the social and spatial organization of computer gaming." Leisure Studies, 22, 1-15.

Budhathoki, N.R. , \& Haythornthwaite, C. (2013). "Motivation for open collaboration: Crowd and community models and the case of OpenStreetMap." American Behavioral Scientist, 57(5),

548-575.

Budziszewski, J. (1992). True tolerance: Liberalism, and the necessity of judgment. New

Brunswick, NJ: Transaction.

Campbell, A. (2010). "Volunteering at the stock camp: Negotiating social positions." World Leisure Journal, 52(3), 222-231.

Carothers, P. , Vaske, J.J. , \& Donnelly, M.P. (2001). "Social values versus interpersonal conflict among hikers and mountain bikers." Leisure Sciences, 23, 23-47.

Chang, K. (2011). "Jack Oliver, Who proved continental drift, dies at 87." New York Times, 12 January (online edition).

Chick, G. (2006). "Anthropology/prehistory of leisure." In C. Rojek , S. M. Shaw , \& A. J. Veal (Eds.), A handbook of leisure studies (pp. 41-54). New York: Palgrave Macmillan.

Cohen, J. (2002). Protestantism and capitalism: The mechanisms of influence. New York: Aldine de Gruyter.

Cohen-Gewerc, E. , \& Stebbins, R.A. (Eds.) (2007). The pivotal role of leisure education: Finding personal-fulfillment in this century. State College, PA: Venture.

Crawford, D. , Jackson, E.L. , \& Godbey, G. (1991). "A hierarchical model of leisure constraints." Leisure Sciences, 13, 309-320.

Cresswell, T. (2013). Place: A short introduction. New York: Wiley.

Crouch, D. (2006). "Geographies of leisure." In C. Rojek, S. M. Shaw , \& A. J. Veal (Eds.), A handbook of leisure studies (pp. 125-139). Houndmills, UK: Palgrave Macmillan.

Csikszentmihalyi, M. (1990). Flow: The psychology of optimal experience. New York, NY: Harper \& Row.

Cunningham, A. , \& Williams, P. (1993). "De-centring the "big picture": The origins of modern science and the modern origins of science." The British Journal for the History of Science, 26, 407-432. doi:10.1017/S0007087400031447.

Cushman, G. , Veal, A. J. , \& Zuzanek, J. (Eds.) (2005). Free time and leisure participation: International perspectives. Wallingford, UK: CAB International.

Davidson, L. , \& Stebbins, R. A. (2011). Serious leisure and nature: Sustainable Consumption in the Outdoors. Houndmills, UK: Palgrave Macmillan.

de Certeau, M. (1984). The practice of everyday life, trans. by S. Rendall . Berkeley, CA: University of California Press.

Deegan, M. J. (1983). "A feminist frame analysis of "Star Trek."' Free Inquiry in Creative Sociology, 11, 182-188.

Dimmock, K. (2009). "Finding comfort in adventure: Experiences of recreational SCUBA divers." Leisure Studies, 28(3), 279-295.

Dumazedier, J. (1988). Révolution culturelle du temps libre 1968-1988. Paris: Méridiens Klincksieck.

Durieux, M. B. , \& Stebbins, R. A. (2010). Social entrepreneurship for dummies. Hoboken, NJ: Wiley.

Durkin, K.F. (2007). "Show me the money: Cybershrews and on-line money masochists." Deviant Behavior, 28, 355-378.

The Economist (2006). "The land of pleasure." February 2 (www.Economist.com).

The Economist (2015). "The age of the red pen." August 22.

Edensor, T. (2001). "Performing tourism, staging tourism (re) producing tourist space and practice." Tourist Studies, 1(1), 59-81. 
Egan, T. (1996). "Jet skis vs. peace on islands in battle of San Juan County." New York Times, 16 March (online edition).

Elkington, S. (2014). "Sites of serious leisure." In S. Elkington \& S. Gammon (Eds.), Leisure in mind: Meaning, motives, and learning (pp. 93-111). London: Routledge.

Ellemers, N. (2013). "Connecting the dots: Mobilizing theory to reveal the big picture in social psychology (and why we should do this)." European Journal of Social Psychology, 43(1), 1-8.

Everett, S. (2008). "Beyond the visual gaze? The pursuit of an embodied experience through food tourism." Tourist Studies, 8(3), 337-358.

Everett, S. , \& Aitchison, C. (2008). "The role of food tourism in sustaining regional identity: A case study of Cornwall, South West England." Journal of Sustainable Tourism, 16(2), 150-167.

Fine, G.A. (1983). Shared fantasy: Role-playing games as social worlds. Chicago, IL: University of Chicago Press.

Fine, G. A. (1998). Morel tales: The culture of mushrooming. Cambridge, MA: Harvard University Press.

Finlay, A.K. , Ram, N. , Maggs, J.L. , \& Caldwell, L.L. (2012). "Leisure activities, the social weekend, and alcohol use: Evidence from a daily study of first-year college students." Journal of Studies on Alcohol and Drugs, 73, 250-259.

Finnegan, R. (1989). The hidden musicians: Music-making in an English town. Cambridge, UK: Cambridge University Press.

Frey, B. S. (2008). Happiness: A revolution in economics. Cambridge, MA: MIT Press.

Frey, J. H. , \& Dickens, D. R. (1990). "Leisure as a primary institution." Sociological Inquiry, 60(3), 264-273.

Gammon, S. , \& Robinson, T. (1997). "Sport and tourism: a conceptual framework." Journal of Sport Tourism, 4(3), 11-18.

Gerth, H. , \& Wright, C. W. (Eds.) (1958). From Max Weber: Essays in sociology. New York: Oxford University Press.

Giddens, A. (1986). The constitution of society: Outline of the theory of structuration. Berkeley, CA: University of California Press.

Gini, A. (2001). Myself, my job: Work and the creation of the modern individual. New York, NY: Routledge.

Godbey, G. (1999). Leisure in your life: An exploration, 5th ed. State College, PA: Venture Publishing.

Gravelle, F. , \& Larocque, L. (2005). "Volunteerism and serious leisure: The case of the francophone games." World Leisure Journal, 47(1), 45-51.

Graver, D. K. (1999). Scuba diving. Champaign, IL: Human Kinetics.

Hagan, J. (1991). The disreputable pleasures: Crime and deviance in Canada, 3rd edition. Toronto, ON: McGraw-Hill Ryerson.

Harrington, M. , Cuskelly, G. , \& Auld, C. (2000). "Career volunteering in commodity-intensive serious leisure: Motorsport events and their dependence on volunteers/amateurs." Loisir et Société/Society and Leisure, 23, 421-452.

Harris, M. (1998). "Doing it their way: Organizational challenges for voluntary associations." Nonprofit and Voluntary Sector Quarterly, 27, 144-158.

Harrison, J. (2001). "Thinking about tourists." International Sociology, 16, 159-172.

Hartel, J. (2010). "Hobby and leisure information and its users." In M. J. Bates , \& M. N. Maack (Eds.), Encyclopedia of library and information science, 3rd edition (pp. 3263-3274). New York: Taylor and Francis.

Havner, R. (2007). "Begging for teachers, many say, "I quit," and "crisis" may be looming." Mobile Press-Register 15 July (electronic edition).

Hawks, S. R. (1991). "Recreation in the family." In S. J. Hawks (Ed.), Family research: A sixtyyear review, 1930-1990 (pp. 387-433). New York, NY: Lexington Books.

Hewson, M. (2010). "Agency." In A. Mills , G. Durepos , \& E. Wiebe (Eds.), Encyclopedia of case study research (pp. 13-17). Thousand Oaks, CA: Sage.

Hoggett, P. \& Bishop, J. (1985). "Leisure beyond the individual consumer." Leisure Studies, 4, 21-38.

Holmes, D. (2001). Virtual globalization: Virtual spaces/tourist spaces (Vol. 1). East Sussez, UK: Psychology Press.

Horna, J. (1994). The study of leisure: An introduction. Toronto, ON: Oxford University Press. 
Jackson, E. L. (Ed.) (2005). "Leisure constraints research: Overview of a developing theme in leisure studies." In E. L. Jackson (Ed.), Constraints to leisure (pp. 4-19). State College, PA: Venture.

Jackson. E. L. , \& Scott, D. (1999). "Constraints to leisure." In E. L. Jackson , \& T. L. Burton (Eds.), Leisure studies: Prospects for the twenty-first century (pp. 299-321). State College, PA: Venture.

Jarnatt, D. (2015). "Seasideness: Sense of place at a seaside resort." In S. Gammon \& S.

Elkington (Eds.), Landscapes of leisure: Space, place, and identities (pp. 147-163). Houndmills, UK: Palgrave Macmillan.

Johansen, D.O. (1967). Empire of the Columbia: A history of the Pacific Northwest, 2nd edition. New York, NY: Harper \& Row.

Kando, T. M. \& Summers, W. C. (1971). "The impact of work on leisure." Pacific Sociological Review, 14, 310-327.

Kaplan, M. (1960). Leisure in America: A social inquiry. New York: John Wiley \& Sons.

Kaplan, M. (1975). Leisure: Theory and policy. New York: Wiley.

Karsten, L. , \& Pel, E. (2000). "Skateboarders exploring urban public space: Ollies, obstacles and conflicts." Journal of Housing and the Built Environment, 15, 327-340.

Katz, J. (1988). Seductions of crime: Moral and sensual attractions of doing evil. New York, NY: Basic Books.

Kay, T. (2003). "Leisure, gender, and self in the analysis of family." World Leisure Journal, 45, 4-14.

Kelly, J. R. (1983). Leisure identities and interactions. London, UK: George Allen \& Unwin.

Kelly, J. R. (1990). Leisure, 2nd ed. Englewood Cliffs, NJ: Prentice-Hall.

Kelly, J. R. , \& Godbey, G. (1992). The sociology of leisure. State College, PA: Venture

Publishing.

Kimball, K. (2010). The dirty life: A memoir of farming, food, and love. New Work: Scribner.

Lake, J. G. (2012). "Demetz underground: Busking regulation and the formation of property

rights." New York University Law Review, 87, 1100-1134. Also available at

http://www.nyulawreview.org/sites/default/files/pdf/NYULawReview-87-4-Lake.pdf.

Lambert, R. D. (1995). "Looking for genealogical motivation." Families, 34(2), 149-160.

Lambert, R. D. (1996). "Doing family history." Families, 35(1), 11-25.

Larson, R. W. , Gillman, S. A. , \& Richards, M. H. (1997). "Divergent experiences of family leisure:

Fathers, mothers, and young adolescents." Journal of Leisure Research, 29, 78-97.

Lawrence, L. (2003). "“These are the voyages ..."; interaction in real and virtual space environments in leisure." Leisure Studies, 22, 301-315.

Lefebvre, H. (1991). The production of space. Oxford: Blackwell Publishers.

Leitner, M. J. , \& Leitner, S. F. (2011). Leisure enhancement, 4th ed. Urbana, IL: Sagamore.

Lengkeek, J. , \& Bargeman, B. (1997). "Voluntary associations and leisure: At the core of social change." Loisir et Société/Society and Leisure, 20, 237-255.

Lepp, A. (2009). "Leisure and obligation: An investigation of volunteer tourists' experience at Kenya's Taita Discovery Center." Journal of Leisure Research, 41, 253-260.

Lyng, S. (1990). "Edgework: A social psychological analysis of voluntary risk-taking." American Journal of Sociology, 95(4), 851-886.

Mattar, Y. (2003). "Virtual communities and hip-hop music consumers in Singapore: Interplaying global, local and subcultural identities." Leisure Studies, 22, 283-300.

McCall, G. J. , \& Simmons, J. L. (1978). Identities and interactions, revised edition. New York:

Free Press.

McCarville, R.E. , Shaw, S.M. , \& Ritchie, M. (2013). "Shopping as leisure: A study of avid

shoppers." World Leisure Journal, 55(2), 167-178.

McCormack, S. (2015). "Guy's attempt to take rattlesnake selfie ends with $\$ 153,000$ bill."

Huffington Post, 25 July. http://www.huffingtonpost.com/entry/rattlesnake-selfie-hospital-

bill_55b38198e4b0a13f9d18bf80.

Maffesoli, M. (1996). The time of the tribes: The decline of individualism, trans. by D. Smith . London, UK: Sage Publications.

Maines, D. R. (1982). "In search of mesostructure: Studies in the negotiated order." Urban Life, 11(3), 267-279.

Mannell, R. C. , \& Kleiber, D. A. (1997). A social psychology of leisure. State College, PA:

Venture. 
Marshall, T. H. (1963). Sociology at the crossroads and other essays. London: Heinemann. Martin, W. H. , \& Mason, S. (2004). "Leisure in an Islamic context." World Leisure Journal, 46(1), 4-13.

Mauss, M. (1990). The gift: Forms and function of exchange in archaic societies. New York, NY: Routledge (original published in French in 1954).

Melton, J. G. (2015). "The new age movement."

(http://www.britannica.com/EBchecked/topic/704347/New-Age-movement, retrieved 11 June 2015).

Mitchell. R. G. , Jr. (1983). Mountain experience: The psychology and sociology of adventure. Chicago. IL: University of Chicago Press.

Newmahr, S. (2011). "Homosexality." In C.D. Bryant (Ed.), The Routledge handbook of deviant behavior (pp. 253-259). New Work: Routledge.

Nichols, G. , Homles, K. , \& Baum, T. (2013). "Volunteering as leisure/leisure as volunteering." In T. Blackshaw (Ed.) Routledge handbook of leisure studies (pp. 456-467). London: Routledge. Nimrod, G. (2010). "The fun culture in seniors' online communities." The Gerontologist, 51(2), 226-237.

Olmsted, A. D. (1988). "Morally controversial leisure: The social world of gun collectors." Symbolic Interaction, 11, 277-288.

Olson, E. G. (2006). Personal development and discovery through leisure, 3rd edition. Dubuque, IA: Kendall/Hunt.

Orr, N. (2006). "Museum volunteering: Heritage as 'serious leisure."' International Journal of Heritage Studies, 12(2), 194-210.

Orthner, D. K. (1975). "Leisure activity patterns and marital satisfaction over the marital career." Journal of Marriage and the Family, 37, 91-104.

Parker, S. (1983). Leisure and work. London: George Allen \& Unwin.

Pearce, J. L. (1993). Volunteers: The organizational behavior of unpaid workers. London, UK:

Routledge.

Pedersen, D. M. (1997). "Perceptions of high-risk sports." Perceptual and Motor Skills, 85(2), 756-758.

Rapoport, R. , \& Rapoport, R. N. (1978). Leisure and the family life cycle. London, UK: Routledge and Kegan Paul.

Raymore, L. A. (2002). "Facilitators to leisure." Journal of Leisure Research, 34, 37-51.

Rifkin, J. (2004). The end of work: The decline of the global labor force and the dawn of the postmarket era. New York: Tarcher/Penguin. With new Introduction to paperback edition.

Riesman, D. (1961). The lonely crowd: A study of the changing American character, revised edition. New Haven, CT: Yale University Press.

Rinehart, R. , \& Sydnor, S. (2003). "Proem." In R. Rinehart, \& Sydnor, S. (Eds.), To the extreme: Alternative sports, inside and out. Albany, NY: State University of New York Press.

Roberson, Jr., D. N. (2011). "Free time in an art museum: Planning, gazing and interacting." Leisure Sciences, 33, 70-80.

Roberts, K. (1978). Contemporary society and the growth of leisure. London: Longman.

Roberts, K. (2006). Leisure in contemporary society, 2nd edition. New York, NY: CABI Publishing. Robinson, John P. , and Geoffrey Godbey . (1997.) Time for life: The surprising ways Americans use their time. University Park, Penn.: Pennsylvania State University Press.

Robinson, V. (2013). "Extreme leisure: The case of extreme sporting activities." In T. Blackshaw (Ed.), Routledge handbook of leisure studies (pp. 506-520). Abingdon, UK: Routledge.

Roe, M. , \& Benson, J.F. (2001). "Planning for conflict resolution: Jet-ski use on the Northumberland Coast." Coastal Management, 29, 19-39.

Rojek, C. (1997). "Leisure theory: Retrospect and prospect." Loisir et Société/Society and Leisure, 20, 383-400.

Rojek, C. (1999). "Deviant leisure: the dark side of free-time activity." In E. L. Jackson and T. L. Burton (Eds.), Leisure studies: Prospects for the twenty-first century (pp. 81-96). State College, PA: Venture.

Rojek. C. (2000). Leisure and culture. London: Palgrave.

Rojek, C. (2010). The labour of leisure. London: Sage.

Rosen, N. (2011). "How it started in Yemen: From Tahrir to Taghyir." Jadaliyya, March 18 (online edition). 
Rosenfeld, R. (2011). "The big picture: 2010 presidential address to the American society of criminology." Criminology, 49(1), 1-26.

Samdahl, D. M. (2005). "Making room for "silly" debate: Critical reflections on leisure constraints research." In E. L. Jackson (Ed.), Constraints to leisure (pp. 337-348). State College, PA:

Venture.

Scott, D. (2003). "Constraints." In J. M. Jenkins , \& J. J. Pigram (Eds.), Encyclopedia of leisure and outdoor recreation (pp. 75-78). London: Routledge.

Scott, D. , \& Godbey, G. C. (1992). "An analysis of adult play groups: Social versus serious participation in contract bridge." Leisure Sciences, 14, 47-67.

Seligman, M. E. P. , \& Csikszentmihalyi, M. (2000). "Positive psychology: An introduction." American Psychologist, 55(1), 5-14.

Shaw, S. M. (1985). "The meaning of leisure in everyday life." Leisure Sciences, 7, 1-24.

Shaw, S. M. , \& Dawson, D. (2001). "Purposive leisure: Examining parental discourses on family activities." Leisure Sciences, 23, 217-232.

Shields, R. (1996). "Foreword." In M. Maffesoli , The time of the tribes: The decline of individualism, trans. by D. Smith (pp. ix-xii). London, UK: Sage Publications.

Siegenthaler, K. L. , \& O'Dell, I. (2003). "Older golfers: Serious leisure and successful aging." World Leisure Journal, 45(1), 45-52.

Skolnick, A. (2015). "Free diver Natalia Molchanova descends for fun, then vanishes." New York Times, 4 August (online edition).

Smith, D.H. 2000. Grassroots associations. Thousand Oaks, CA: Sage Publications.

Smith, D. H. , Stebbins, R. A. , \& M. Dover (2006). A dictionary of nonprofit terms and concepts. Bloomington, IN: Indiana University Press.

Sobel, M. E. (1981). Lifestyle and social structure: Concepts, definitions, analyses. New York:

Academic Press.

Spracklen, K. (2011). Constructing leisure: Historical and philosophical debates. Houndmills, UK:

Palgrave Macmillan.

Stebbins, R. A. (1976). "Music among friends: The social networks of amateur musicians."

International Review of Sociology (Series II), 12, 52-73.

Stebbins, R. A. (1979). Amateurs: On the margin between work and leisure. Beverly Hills, CA:

Sage Publications.

Stebbins, R. A. (1980). "Avocational science: The amateur routine in archaeology and

astronomy." International Journal of Comparative Sociology, 21, 34-48.

Stebbins, R. A. (1990). The laugh-makers: Stand-up comedy as art, business, and life-style.

Montreal, QC \& Kingston, ON: McGill-Queen's University Press.

Stebbins, R. A. (1992). Amateurs, professionals, and serious leisure. Montreal, QC and Kingston, ON: McGill-Queen's University Press.

Stebbins, R. A. (1993a). Career, culture and social psychology in a variety art: The magician.

Malabar, FL: Krieger.

Stebbins, R. A. (1993b). Predicaments: Moral difficulty in everyday life. Lanham, MD: University

Press of America.

Stebbins, R. A. (1993c). "Social world, life-style, and serious leisure: Toward a mesostructural analysis." World Leisure and Recreation, 35(spring), 23-26.

Stebbins, R. A. (1993d). Canadian football. A view from the helmet. (reprinted ed.). Toronto, ON:

Canadian Scholars Press. also available in the Digital Library, www.seriousleisure.net .

Stebbins, R. A. (1994). "The liberal arts hobbies: A neglected subtype of serious leisure." Loisir et Société/Society and Leisure, 16, 173-186.

Stebbins, R. A. (1996a). The barbershop singer: Inside the social world of a musical hobby. Toronto, ON: University of Toronto Press.

Stebbins, R. A. (1996b). "Volunteering: A serious leisure perspective." Nonprofit and Voluntary Action Quarterly, 25, 211-224.

Stebbins, R.A. (1996c). Tolerable differences: Living with deviance, 2nd ed. Toronto, ON:

McGraw-Hill Ryerson. Also available at www.seriousleisure.net/Digital Library.

Stebbins, R.A. (1997). "Casual leisure: A conceptual statement." Leisure Studies, 16, 17-25.

Stebbins, R. A. (1998a). The urban francophone volunteer: Searching for personal meaning and community growth in a linguistic minority, Vol. 3, No. 2 (New Scholars-New Visions in Canadian Studies quarterly monographs series). Seattle, WA: University of Washington. 
Stebbins, R. A. (1998b). After work: The search for an optimal leisure lifestyle. Calgary, AB: Detselig. Also available in the Digital Library at www.seriousleisure.net.

Stebbins, R. A. (2000a). "Obligation as an aspect of leisure experience." Journal of Leisure Research, 32, 152-155.

Stebbins, R. A. (2000b). "Optimal leisure lifestyle: Combining serious and casual leisure for personal well-being." In M. C. Cabeza (Ed.), Leisure and human development: Proposals for the 6th World Leisure Congress. (pp. 101-107). Bilbao, Spain: University of Deusto.

Stebbins, R. A. (2001a). "Volunteering - mainstream and marginal: Preserving the leisure experience." In M. Graham , \& M. Foley (Eds.), Volunteering in leisure: Marginal or inclusive? (LSA Publication No. 75) (pp. 1-10). Eastbourne, UK: Leisure Studies Association.

Stebbins, R. A. (2001b). New directions in the theory and research of serious leisure, Mellen Studies in Sociology, vol. 28. Lewiston, NY: Edwin Mellen.

Stebbins, R. A. (2002). The organizational basis of leisure participation: A motivational exploration. State College, PA: Venture.

Stebbins, R. A. (2003). "Boredom in free time." Leisure Studies Association Newsletter, 64 (March), 29-31. Also freely available at www.seriousleisure.net-Digital Library.

Stebbins, R. A. (2004). "Fun, enjoyable, satisfying, fulfilling: Describing positive leisure experience." Leisure Studies Association Newsletter, 69 (November), 8-11. Also freely available at www.seriousleisure.net-Digital Library.

Stebbins, R. A. (2004/2014). Between work and leisure: The common ground of two separate worlds. New Brunswick, NJ: Transaction Publishers (paperback edition with new Preface, 2014).

Stebbins, R. A. (2005a). "Choice and experiential definitions of leisure." Leisure Sciences, 27, 349-352.

Stebbins, R. A. (2005b). Challenging mountain nature: Risk, motive, and lifestyle in three hobbyist sports. Calgary, AB: Detselig.

Stebbins, R. A. (2005c). "Project-based leisure: Theoretical neglect of a common use of free time." Leisure Studies, 24, 1-11.

Stebbins, R. A. (2006a). "Contemplation as leisure and non-leisure." Leisure Studies Association Newsletter 73 (March), 21-23. Also available at www.seriousleisure.net/ Digital Library, "Leisure Reflections No. 11."

Stebbins, R. A. (2006b). "Discretionary time commitment: Effects on leisure choice and lifestyle." Leisure Studies Association Newsletter, no. 74 (July), pp. 18-20. Also available at www.seriousleisure.net/ Digital Library, "Leisure Reflections No. 12."

Stebbins, R. A. (2007/2015). Serious leisure: A perspective for our time, New Brunswick, NJ: Transaction (published in paperback in 2015 with new Preface).

Stebbins, R. A. (2008). "The leisure basis of caring." Leisure Studies Association Newsletter 79 (March), 34-37. Also available at www.seriousleisure.net-Digital Library, "Leisure Reflections No. 17."

Stebbins, R. A. (2009a). Personal decisions in the public square: Beyond problem solving into a positive sociology. New Brunswick, NJ: Transaction.

Stebbins, R. A. (2009b). Leisure and consumption: Common ground, separate worlds.

Houndmills, Basingstoke, UK: Palgrave Macmillan.

Stebbins, R. A. (2009c). "New leisure and leisure customization." World Leisure Journal, 51(2), 78-84.

Stebbins, R. A. (2012). The idea of leisure: First principles, New Brunswick, NJ: Transaction.

Stebbins, R. A. (2013a). Homo otiosus: Who is this creature, does it exist, should it matter?

Leisure Studies Association Newsletter, 94 (March): 19-21 (also freely available at

www.seriousleisure.net/ Digital Library, Leisure Reflections No. 32).

Stebbins, R. A. (2013b). "Unpaid Work of Love: Defining the Work-Leisure Axis of Volunteering." Leisure Studies, 32, 339-345.

Stebbins, R. A. (2013c). "The longitudinal process of grounded theory development: A case study in leisure research." Thousand Oaks, CA: Sage. DOI:

http://dx.doi.org/10.4135/978144627305013509771

Stebbins, R. A. (2013d). "Leisure." In V. Smith , \& G.J. Golson (Eds.), Sociology of work: An encyclopedia. Thousand Oaks, CA: Sage.

Stebbins, R. A. (2013e). The committed reader: Reading for utility, pleasure, and fulfillment in the twenty-first century. Lanham, MD: Scarecrow Press. 
Stebbins, R.A. (2013f). Work and leisure in the Middle-East: The common ground of two separate worlds. New Brunswick, NJ: Transaction.

Stebbins, R.A. (2013g). Planning your time in retirement: How to cultivate a leisure lifestyle to suit your needs and interests. Lanham, MD: Rowman \& Littlefield.

Stebbins, R.A. (2013h). "The spaces of the serious pursuits: A typology." Leisure Studies

Association Newsletter, 95 (July): 21-24. Also freely available at www.seriousleisure.net/Digital

Library, Leisure Reflections No. 33.

Stebbins, R. A. (2014). Careers in serious leisure: From dabbler to devotee in search of fulfillment. Houndmills, UK: Palgrave Macmillan.

Stebbins, R.A. (2015). Leisure and the motive to volunteer: Theories of serious, casual, and project-based leisure. Houndmills, UK: Palgrave Macmillan.

Stebbins, R. A. (in press, a). "The sociology of leisure and recreation." In K.O. Korgen (Ed.), The Cambridge handbook of sociology. New York: Cambridge University Press.

Stebbins, R. A. (in press, b). "Leisure music production: Its spaces and places." In R. Mantie \& G. D. Smith (Eds.), Oxford handbook of music making and leisure. New York: Oxford University Press.

Stokowski, P. A. , \& Lee, R. G. (1991). "The influence of social network ties on recreation and leisure: An exploratory study." Journal of Leisure Research, 23, 95-113.

Sylvester, C. (1999). "The Western idea of work and leisure: Traditions, transformations, and the future." In E.L. Jackson \& T.L. Burton (Eds.), Leisure studies: Prospects for the twenty-first century (pp. 17-34). State College, PA: Venture.

Szalai, A. (Ed.). (1972). The use of time: Daily activities of urban and suburban populations in twelve countries. The Hague: Mouton.

Szasz, T. (1974). Ceremonial chemistry. Garden City, NY: Doubleday.

Tanner, J. , Asbridge, M. , \& Wortley, S. (2015). "Leisure worlds: Situations, motivations and young people's encounters with offending and victimization." Youth \& Society, 47(2), 199-221.

Thompson, M. C. (1997). "Volunteer firefighters: Our silent heroes." Unpublished doctoral dissertation, Department of Sociology, University of Calgary.

Truzzi, M. (1972). "The occult revival as popular culture." The Sociological Quarterly, 13, 16-36.

Tuan, Y. F. (1977) Space and Place, Minneapolis: University of Minnesota Press.

Turner, J. H. (2005). "A new approach for theoretically integrating micro and macro analysis." In

C. Calhoun , C. Rojek , \& B. Turner (Eds.), The SAGE handbook of sociology (pp. 405-423).

London: Sage.

Turner, R. H. , \& Killian, L. M. (1987). Collective behavior, 3rd edition. Englewood Cliffs, NJ: Prentice-Hall.

Unruh, D. R. (1979). "Characteristics and types of participation in social worlds." Symbolic Interaction, 2, 115-130.

Unruh, D. R. (1980). "The nature of social worlds." Pacific Sociological Review, 23, 271-296. Veblen, T. (1999). The theory of the leisure class: An economic study of institutions. New York: Macmillan.

Warde, A. (2005). "Consumption." In T. Bennett , L. Grossberg , \& M. Morris (Eds.), New keywords: A revised vocabulary of culture and society (pp. 57-59). Oxford, UK: Blackwell. Weber, M. (1930). The Protestant ethic and the spirit of capitalism, translated by T. Parsons . New York: Scribner's.

Weber, M. (1968 [1921]). Economy and Society, 3 Vols. Totowa, NJ: Bedminster Press. Wheaton, B. (2004). "Introduction: Mapping the lifestyle sport-scape." In B. Wheaton (Ed.), Understanding lifestyle sports: Consumption, identity and difference. Abington, UK: Routledge. Williams, R. M., Jr. (2000). "American society." In E.F. Borgatta , \& R.J.V. Montgomery (Eds.), Encyclopedia of sociology, 2nd edition, Vol. 1 (pp. 140-148). New York: Macmillan.

Williams, T. R. (2000). Getting organized: A history of amateur astronomy in the United States. Doctoral dissertation, Rice University (USA).

Wilson, K. (1995). "Olympians or lemmings? The postmodernist fun run." Leisure Studies, 14, 174-185.

Wood, K.R. (1996). "Jet-ski ban is making waves-San Juan county law prompts a suit and national attention." The Seattle Times, Friday 28 June (online edition).

Woodside, A. G. , Caldwell, M. , \& Spurr, R. (2006). "Advancing ecological systems theory in lifestyle, leisure, and travel research." Journal of Travel Research, 44, 259-272. 
Wynveen, C. J. , Kyle, G. T. , \& Sutton, S. G. (2010). "Place meanings ascribed to marine settings: The case of the Great Barrier Reef Marine Park." Leisure Studies, 32, 270-287. Yoder, D. G. (1997). "A model for commodity intensive serious leisure." Journal of Leisure Research, 29, 407-429.

Zuzanek, Jiri. (1996). Canada. In World leisure participation: Free time in the global village. Edited by Grant Cushman, A. J. Veal , and Jiri Zuzanek. Wallingford, UK: CAB International. 